\title{
HBV-DNA Pozitif Olgularda HDV-RNA Sıklığı
} Prevalence of HDV-RNA in HBV-DNA Positive Patients

\author{
Mustafa BERKTAŞ1, Mehmet PARLAK2, Aytekin ÇIKMAN3, Metin YÜCE1, Görkem YAMAN4 \\ ${ }^{1}$ Yüzüncü Yıl Üniversitesi Tıp Fakültesi, Tıbbi Mikrobiyoloji Anabilim Dalı, Van, Türkiye \\ 2 Van Bölge Eğitim ve Araştırma Hastanesi, Mikrobiyoloji Labaratuvarı, Van, Türkiye \\ 3Mengücek Gazi Eğitim Araştırma Hastanesi, Mikrobiyoloji Labaratuvarı, Erzincan, Türkiye \\ ${ }^{4}$ Düzen Labrovatuvarlar Grubu Mikrobiyoloji ve Tüberküloz Birimi, Istanbul, Türkiye
}

ÖZT

Amaç: Replikasyon için Hepatitis B virüsüne (HBV) gereksinim duyan ve birlikte ağır gidișli akut ve kronik hepatitlere neden olan HDV virüs varlığı, bölgemizde diğer bölgelere oranla daha yüksek oranlarda saptanmaktadır. Çalışmada, HBV-DNA'sı pozitif olan akut hepatit B, kronik hepatit B ve HBsAg taşıyıcılarında HDV-RNA'nın sıkığı araştıııldı.

Gereç ve Yöntemler: Eylül 2009-Haziran 2010 tarihleri arasında laboratuvarımızda HBV-DNA'sı pozitif olarak tespit edilen ve HDV-RNA tetkiki yapılan 145 serum örneğinin sonuçları değerlendirildi. Serum örneklerine manyetik partikülle izolasyon teknolojisi (Easy One) kullanılarak izolasyon ișlemi yapıldıktan sonra HBV-DNA (HBV Rotor Gene PCR Kit, Qiagen ${ }^{\circledR}$, Hilden) ve HDV-RNA (Primer Design, UK) varlığı araştıııldı.

Bulgular: HBV-DNA pozitif olduğu tespit edilen toplam 145 hasta serum örneğinin 15 'inde $(\% 10,3)$ HDV-RNA pozitifliği tespit edildi.

Sonuç: Yapılan çalışmada bulunan $\% 10,3^{\prime}$ lük oran bölgemiz için daha önce yapılan çalıssmalardan elde edilen verilerle uyumludur. HBV DNA negatif, delta lgG pozitif, HDV RNA negatif kronik HBV+HDV olgularının varlığı da düsünüldügünde bu oranların daha da yükselebileceği bir gerçektir. Akut ve kronik karaciğer hastalıliarının HDV açısından da taranması, HBsAg taşıyıcılarına çevresel ve bariyer önlemlerin uygulanması, özellikle yüksek risk grubundaki anti-HBc total negatif kisilerin hepatit B'ye karsı asılanması. HDV ile mücadelede havati önem taşımaktadır. (Viral Hepatit Dergisi 2012; 18(1): 34-6)

Anahtar Kelimeler: HBV-DNA, HDV-RNA, PCR, serum

\begin{abstract}
Objective: Hepatitis D virus (HDV) requires Hepatitis B virus(HBV) for replication and may cause to severe acute and chronic hepatitis. HDV is more frequently detected in our region In this study, HDV-RNA frequency was investigated in HBVDNA-positive acute hepatitis B, chronic hepatitis B and HBsAg carriers.

Materials and Methods: Results of 145 serum samples were examined for HDVRNA that was detected as HBV-DNA positive in our laboratory from September 2009 to June 2010. After isolation in serum samples using magnetic particle isolation technology (Easy One), the HBV-DNA (HBV Rotor Gene PCR Kit, Qiagen ${ }^{\circledR}$, Hilden) and HDV-RNA (Primer Design, UK) were examined.

Results: From a total of 145 patients with HBV-DNA positive serum samples, HDVRNA positivity was found in $15(10.3 \%)$.

Conclusion: Ratio that was obtained as $10.3 \%$ in this study is compatible with the data obtained from previously studies. Considering the presence of HBV DNA negative, delta lgG positive and HDV RNA negative cases with chronic Hepatitis $D$, it should be addressed that the given rate would further rise. Routine HDV screening in patients presenting with findings of acute or chronic liver diseases, implementation of appropriate isolation precautions for HBV and community-wide vaccination against HBV are crucial to combat with HDV infection. (Viral Hepatitis Journal 2012; 18(1): 34-6)

Key words: HBV-DNA, HDV-RNA, PCR, serum
\end{abstract}

\section{Giriş}

Hepatitis Delta virüsü (HDV), yalnızca insanlarda görülen, 36 - 43 nm çapında tek iplikçikli RNA'ya sahip bir virüs olup replikasyon için Hepatitis B virüsü (HBV)‘na gereksinim duymaktadır (1,2). HDV, ilk olarak 1977 yılında Rizzetto ve ark. tarafından kronik Hepatit B virüs (HBV) ile enfekte bazı hastaların hepatosit hücrelerinde yeni bir nükleer antijen olarak bulunmuştur. 1980 yılında HBV'ye gereksinim duyan ayrı bir patojen olduğu anlaşıımış ve 1983 yılında Hepatit Delta virüsü olarak adlandırılmıştır $(1,3)$.

Hepatit B yüzey antijeni (HBsAg) taşıyıcıları ve HBV ile enfekte hastalar, toplumun diğer fertleri için enfeksiyon kaynağıdırlar, ancak HDV bu kişilerde hastalığın seyrini değiştirek ciddi anlamda tehdit oluşturmaktadır (1). Hepatit D Virüsü, HBV gibi, çoğunlukla kontamine kan ve kan ürünlerinin parenteral verilmesiyle, daha az oranda ise vücut sıvıları ile ya da cinsel yolla bulaşmaktadır. Hijyenik olmayan

Yazışma Adresi/Address for Correspondence: Dr. Mehmet Parlak, Van Bölge Eğitim ve Araştırma Hastanesi, Mikrobiyoloji Labaratuvarı, Van, Türkiye Tel.:+90 4322177604 (2565) E-mail: mehmetparlak65@hotmail.com Received/Geliș tarihi: 18.01.2011 Accepted/Kabul tarihi: 14.05.2012 
koşullarda yaşama, akupunktur, açık yaralar ve sivrisinekler, HDV'nin epidemi yapmasına neden olabilmektedir. Intravenöz (IV) ilaç bağımlıları, hemofili hastaları gibi sık kan transfüzyonu yapılan hastalar ve hemodiyaliz hastaları ile hayat kadınları bu enfeksiyona yakalanma açısından daha yüksek risk altındadırlar (4).

HDV enfeksiyonu sonucunda diğer formlardan daha şiddetli hepatit gelişmektedir (5). HBV varlığında enfeksiyon oluşturabilmesi nedeniyle HDV'nun yol açtığı patolojik ve klinik tablolar; akut HBV enfeksiyonu ile birlikte akut HDV enfeksiyonu, kronik HBV enfeksiyonu olanlarda (HBsAg taşıyıcıları, HBV'na bağlı kronik hepatit ve siroz gibi) akut HDV enfeksiyonu ve kronik HDV enfeksiyonu olmak üzere üç şekilde ortaya çıkmaktadır $(6,7)$.

Serumda HDV tespiti için spesifik antikor ve antijen testleri kullanımaktadır. Nükleik asit saptama tekniklerinin gelişmesi ile HDV enfeksiyonunun klinik evresinin ve tedaviye yanıtın daha iyi değerlendirilmesi sağlanmıştır (1).

Çalışmada, HBV-DNA'sı pozitif olan akut hepatit B, kronik hepatit B ve HBsAg taşıyıcılarında HDV-RNA'nın sıklığı araştırılmıştır.

\section{Gereç ve Yöntem}

Çalışmada, Eylül 2009-Haziran 2010 tarihleri arasında Yüzüncü Yıl Üniversitesi Tıp Fakültesi Mikrobiyoloji laboratuvarında HBV-DNA'sı pozitif olarak tespit edilen ve HDVRNA tetkiki yapılan 145 serum örneğinin sonuçları değerlendirildi. Laboratuvarımıza jelli tüpler (Green Cross MS, Green Vac-Tube $5 \mathrm{ml}$ ) içerisinde gelen serum örneklerine manyetik partikülle izolasyon teknolojisi (Easy One) kullanılarak izolasyon işlemi yapıldıktan sonra HBV-DNA (HBV Rotor Gene PCR Kit, Qiagen ${ }^{\circledR}$, Hilden) ve HDV-RNA (Primer Design, UK) varlığı araştııılı. HBV-DNA için $10 \mathrm{IU} / \mathrm{ml}$ ve üzeri değerler pozitif olarak değerlendirildi. HDV-RNA, bir serum örneğinde 9 kopya/ml bulunmuş, diğer örnekler yüksek düzeyde pozitif olarak tespit edilmiştir.

\section{Bulgular}

HBV-DNA pozitif olduğu tespit edilen toplam 145 hasta serum örneğinin 15 'inde $(\% 10,3)$ HDV-RNA pozitifliği saptandı.

\section{Tartışma}

HBsAg pozitif bireylerde yapılan anti-HDV seroprevalans çalışmalarında HDV enfeksiyonunun tüm dünyada görülebildiği, ancak dağılımının uniform olmadığı saptanmıştır (4). Tüm dünyada yaklaşık 2 milyar insan HBV ile enfekte olmuştur ve yaklaşık 350 milyon kişi de kronik taşıyıcı durumundadır. Yine, dünya nüfusunun 10 milyonunun HDV ile enfekte olduğu tahmin

Tablo 1. Çeşitli merkezlerde HDV sıklığı

\begin{tabular}{|c|c|c|c|c|c|}
\hline Araştırmacı & YII & Yöntem & Bölge & HDV sıklığı & HBV Durumu \\
\hline Berktaş ve ark. (12) & 1995-1996 & ELISA & Van & 3,3 & HBsAg (+) hastalar \\
\hline Güdücüoğlu ve ark. (13) & 2003-2004 & ELISA & Van & $\begin{array}{l}19,5 \\
7,7 \\
24,8\end{array}$ & $\begin{array}{c}\text { HBsAg (+) hastalar } \\
\text { Akut HBV } \\
\text { Kronik HBV }\end{array}$ \\
\hline Kurdoğlu ve ark. (14) & 2004-2005 & ELISA & Van & $\begin{array}{l}2,1 \\
7,1 \\
5,6\end{array}$ & $\begin{array}{c}\text { HBsAg }(+) \text { hastalar } \\
\text { Akut HBV } \\
\text { Kronik HBV }\end{array}$ \\
\hline Türkdoğan ve ark. (15) & 2005 & ELISA & Van & $\begin{array}{l}5,0 \\
16,0\end{array}$ & $\begin{array}{c}\text { HBsAg }(+) \text { hastalar } \\
\text { Kronik HBV }\end{array}$ \\
\hline Arabacı ve ark. (16) & 2002 & ELISA & Van & $\begin{array}{c}27,7 \\
4,0 \\
56,2\end{array}$ & $\begin{array}{c}\text { HBsAg (+) hastalar } \\
\text { Akut HBV } \\
\text { Kronik HBV }\end{array}$ \\
\hline Özekinci ve ark. (17) & 2002 & ELISA & Diyarbakır & 15,4 & $\begin{array}{c}\text { HBV-DNA'sı } 5 \mathrm{pg} / \mathrm{mL}^{\prime} \text { nin } \\
\text { altındaki hastalar }\end{array}$ \\
\hline Demirdal ve ark. (18) & 2009 & ELISA & Afyon & $\begin{array}{l}2,7 \\
2,9\end{array}$ & $\begin{array}{c}\text { HBsAg }(+) \text { hastalar } \\
\text { Kronik HBV }\end{array}$ \\
\hline Azap ve ark. (19) & 1987-2003 & ELISA & Ankara & $\begin{array}{l}7,1 \\
3,5\end{array}$ & $\begin{array}{c}\text { HBsAg }(+) \text { hastalar } \\
\text { Akut HBV }\end{array}$ \\
\hline Cesur ve ark. (9) & $1990-2000$ & ELISA & Ankara & $\begin{array}{l}5,5 \\
8,8\end{array}$ & $\begin{array}{l}\text { HBsAg }(+) \text { hastalar } \\
\text { Kronik HBV }\end{array}$ \\
\hline İskender ve ark. (8) & 2004-2005 & ELISA & Ankara & 2,3 & Belirtilmemiş \\
\hline Kaya ve ark. (20) & 2006-2007 & ELISA & Trabzon & $\begin{array}{l}3,6 \\
3,3\end{array}$ & $\begin{array}{l}\text { HBsAg }(+) \text { hastalar } \\
\text { Kronik HBV }\end{array}$ \\
\hline
\end{tabular}


edilmektedir (8). HDV enfeksiyonunun prevalansı, yüksek, orta ve düşük olmak üzere üç epidemiyolojik grup altında incelenmektedir (6). Ülkemizin de içinde bulunduğu Akdeniz ülkeleri orta endemik bölgeler içerisinde bulunmaktadır $(8,9)$.

Türkiye'de kronik karaciğer hastalıklarının en önemli nedeni viral hepatitler olup 1980 yılından beri yapılan çalışmalara bakıldığında ülke genelinde en sık neden olarak HBV görülmektedir. Ülkemizde batı bölgelerinde kronik karaciğer hastalığı nedeni olarak ikinci ve üçüncü sırada HCV ve HDV görülürken Doğu ve Güneydoğu Anadolu bölgelerinde bu sıralama HDV ve HCV olarak yer değiştirmektedir. Son yıllarda ülkemizde batı bölgelerinde HBV ile mücadele nedeni ile HBV ve buna bağlı olarak da HDV prevalansında azalma tespit edilmiştir (10).

Türkiye'de yapılan çalışmalarda asemptomatik hepatit $B$ taşıyıcılarında \% 1,05-5,2 arasında, akut B tipi viral hepatitlilerde \%6,35-22 arasında ve kronik karaciğer hastalığı olanlarda ise \%31,1-58 arasında anti-HDV prevalansı sonuçları bildirilmiştir (9). Doğu ve Güneydoğu Anadolu bölgelerinde anti-HDV sıklık oranları Batı bölgelerine oranla çok daha yüksektir (8). Batıda Akut Hepatit B'li kişilerde anti-HDV pozitifliği \%0-11 arasında değişmekte iken Güneydoğu bölgelerinde bu oranlar \%20-25 arasında değişmektedir (11). Ülkemizde çeşitli merkezlerde yapılan anti-HDV sonuçlarına göre HDV sıklığı Tablo'da gösterilmiştir.

Yapılan çalışmada bulunan \%10,3'lük oran, bölgemiz için daha önce yapılan çalışmalardan elde edilen verilerle uyumludur. HBV DNA negatif, delta IgG pozitif, HDV RNA negatif kronik HBV+HDV olgularının varlığı da düşünüldüğünde bu oranın daha da yükselebileceği bir gerçektir.

Hepatit D Virüsü enfeksiyonunun, diğer viral hastalıkların çoğunda olduğu gibi radikal tedavisi olmadığından korunma ön plandadır. lyi bir korunma için hastalığın epidemiyolojisinin iyi bilinmesi gereklidir. HBsAg taşıyıcılarında çevresel ve bariyer önlemlerin uygulanması, özellikle yüksek risk grubundaki antiHBc total negatif kişilere hepatit B aşısı yapılması, HBV'nin yanı sıra kişiyi HDV'ye karşı koruyacaktır (4).

Sonuç olarak, bölgemizde HDV enfeksiyonu hâlâ sık olarak görülmektedir (11). HDV enfeksiyonunu önleyebilmek için, korunmanın ön planda tutulması, akut ve kronik karaciğer hastalıklarının takibinde mutlaka HDV aranması, HBsAg taşıyıcılarında çevresel ve bariyer önlemlerin uygulanması, özellikle yüksek risk grubundaki anti-HBc total negatif kişilere hepatit B aşısı yapılması HDV ile mücadelede hayati önem taşımaktadır (4).

\section{Kaynaklar}

1. Iyigün $C P, A v c ı$ IY. Hepatit $B$ ve $D$ virüsleri. In: Başustaoğlu $A$ ed. Klinik Mikrobiyoloji. Çev: Murray PR. Manual of Clinical Microbiology. 9. Baskı. Ankara: Atlas Kitapçılık, 2009: Cilt 2; 16411659.

2. Badur S. Viral Hepatitler (HAV, HBV, HDV). In: Ustaçelebi Ş, Abacıoğlu H, Badur S eds. Moleküler, Klinik ve Tanısal Viroloji. Ankara: Güneş Kitabevi, 2004: 198-202.

3. Rizzetto M, Canese MG, Aricò S, Crivelli O, Trepo C, Bonino F, et al. Immunofluorescence detection of a new antigen/antibody system (delta/anti-delta) associated with hepatitis B virus in liver and serum of HBsAg carriers. Gut. 1977; 18: 997-1003.

4. Baylan O, Güney Ç. B Hepatitli Hastaların ve Asemptomatik HBsAg Taşıyıcılarının Korkulu Rüyası: Delta Virusu. Infeksiyon Derg. 2002: 16: 249-57

5. Rizzetto M, Verme G. Delta Hepatitis. J Hepatol. 1985: 1; 187-93.

6. Cengiz AT, Dolapçı GI. Hepatit D virusu (HDV) ve infeksiyonları. OMÜ Tip Derg. 1997: 14; 231-9

7. Bozdayı MA, Kural A, Özdemir S, Cengiz D, Türkvan M. Donörlerde HBsAg ve Delta Antikoru (anti-HD) Sıklığı. Endoskopi Derg. 1991: 3.

8. Iskender G, Oğan MC, Saylır K, Dirim EB, Batı S, Çimentepe M, et al. Hepatit B Virüsü Infeksiyonlu Olgularda Anti-HDV Sıklı̆ı. Acta Oncologica Turcica. 2006; 39: 99-100.

9. Cesur S, Kuvat SV, Çiftçi A, Balık I. Kronik Hepatit B Infeksiyonlu Hastalarda Anti-Hepatit Delta Virus (Anti-HDV) ve Anti-Hepatit C Virus (Anti-HCV) Antikor Sıklığı. Infeksiyon Derg 2003; 17: 395-7.

10. Değertekin H, Yalçın K, Yakut M. The prevalence of hepatitis delta virus infection in acute and chronic liver diseases in Turkey: An analysis of clinical studies. Turk J Gastroenterol. 2006: 17: 25-34.

11. Değertekin H, Yükselen AV, Dursun M, Yalçın K. Seroepidemiology of delta hepatitis in Turkey. Turk J Gastroenterol 1999: 10; 316-27.

12. Berktaş $M$, Türkdoğan $K$, Bozkurt $H$, Yavuz MT, Irmak $H$, Andiç Ş. Hepatit B virus enfeksiyonu geçiren hastalarda Delta antikoru araştıııması. Viral Hepatit Derg 1998: 4; 28-9.

13. Güdücüoğlu $H$, Altunbaş $S$, Bozkurt $H$, Baykal $S$, Berktaş $M$. Van Askeri Hastanesinde HBsAg Pozitif Askerlerde Delta Antikorunun Araştıııması. Van Tıp Derg 2006: 13: 118-20.

14. Kurtoğlu MG, Üstün $C$, Bozkurt H, Tuncer O, Berktaş M. Türkiye'nin Doğusunda Hepatit B Virus Enfeksiyon Dönemlerinde Saptanan Hepatit D Virus Seroprevalansı. Viral Hepatit Derg 2009; 14: 27-32.

15. Türkdoğan MK, Bozkurt H, Uygan I, Tuncer I, Irmak H, Buzgan T, et al. Chronic hepatitis delta virus infection in Van region of eastern Turkey. Turk J Gastroenterol. 2005; 16: 17-20.

16. Arabacı F, Deveci A, Evirgen Ö, Yıldız Ö. Van'da HBV ile Infekte Kişilerde Anti-HDV Pozitifliği. Viral Hepatit Derg. 2004: 9; 32-5.

17. Özekinci T, Akpolat N, Atmaca S, Elçi S, Mete M. Hybrid Capture Yöntemi ile HBV-DNA'sı $5 \mathrm{pg} / \mathrm{ml}$ 'nin altında, HBsAg'si Pozitif Hastalardaki Total HDV Antikorlarının aranması. Viral Hepatit Derg. 2005: 10; 34-6.

18. Demirdal T, Demirtürk N, Așcı Z. Afyonkarahisar ilinde Hepatit Delta Virusu seroprevalansı. Viral Hepatit Derg. 2009; 14: 104-7.

19. Azap A, Polat H, Memikoğlu O, Birengel S, Kader Ç, Tekeli E. Hapatit Delta Seroprevalansı: Rutin Laboratuvar Test Çalışmalarının Önemi. Viral Hepatit Derg. 2005: 10; 85-9.

20. Kaya S. Polikliniğimizde izlenen Kronik Hepatit B Virüs infeksiyonlu Hastalarda Anti-HDV Sıklığı. Viral Hepatit Derg. 2006; 11: 154-7. 